PAPIERs de Recherche du CSI - CSI Working PAPERS Series

$N^{\circ} 020$

2010

The problem with economics:

naturalism, critique and performativity

Fabian Muniesa

Centre de Sociologie de l'Innovation Mines ParisTech

fabian.muniesa(a)mines-paristech.fr

Centre de Sociologie de l'INNOVAtion

MINES PARISTECH / CNRS UMR 7185

60 Boulevard Saint-Michel

75272 Paris cedex 06 FRANCE

http://www.csi.ensmp.fr/ 
Cette collection a pour but de rendre aisément disponible un ensemble de documents de travail et autres matériaux de discussion issus des recherches menées au CSI (CENTRE DE SOCIOLOGIE DE L'INNOVATION).

Tous les droits afférant aux textes diffusés dans cette collection appartiennent aux auteurs.

Des versions ultérieures des papiers diffusés dans cette collection sont susceptibles de faire l'objet d'une publication. Veuillez consulter la base bibliographique des travaux du CSI pour obtenir la référence exacte d'une éventuelle version publiée.

\section{CSI WORKING PAPERS SERIES}

The aim of this collection is to make easily available a set of working papers and other materials for discussion produced at the CSI (CENTRE DE SOCIOLOGIE DE L'INNOVATION)

The copyright of the work made available within this series remains with the authors.

Further versions of these working papers may have been submitted for publication. Please check the bibliographic database of the CSI to obtain exact references of possible published versions. 


\title{
The Problem with Economics: Naturalism, Critique and Performativity
}

\author{
Fabian Muniesa
}

The idea according to which economics does contribute in a performative way to the construction, enactment, initiation, transformation or maintenance of economic things has gained some relevance in the social sciences, but has also raised scholarly discomfort and criticism. ${ }^{1}$ The hypothesis developed in this paper is that such discomfort can serve as a useful vehicle to analyze naturalism in economic reason, or, more precisely, to explore some features of a somewhat naturalistic style that often characterizes the taking into consideration of economic things. The intellectual device that I use throughout the paper in order to tackle this question consists of a series of "breaching thought experiments" in which the behavior of economic reason is confronted to annoying situations (one being the claim that economics is performative) with the purpose of showing what is taken for granted when the naturalness of economic things is at stake.

I consider here "economic reason" in a wide sense, and I refer with this expression to a variety of things: traits of modern economic thought and of economic science (i.e. economics), but also aspects of economic logic operating in economic reality, or

\footnotetext{
${ }^{1}$ Donald MacKenzie, Fabian Muniesa and Lucia Siu, ed., Do Economists Make Markets? On the Performativity of Economics (Princeton, NJ: Princeton University Press, 2007). This paper was initially conceived as a contribution to the Colloque de Cerisy organized by Philippe Descola and Bruno Latour on "The Historical Anthropology of Scientific Reason” (12-19 July, 2006), and was also presented at the Goldsmiths College Conference on “Markets, Economics, Culture and Performativity” (6 March, 2007). A later version as been prepared for a special issue edited by Silvia Posocco and Sadie Wearing on "Performativities: Contexts, Domains, Perspectives”. I would like to thank Bruno Latour, Philippe Descola, Will Davies, José Ossandón, Scott Lash, Keith Hart, Donald MacKenzie, Michel Callon, Daniel Beunza, Emilio Luque and David Teira for their remarks on this unusual essay. This version: January 2010.
} 
characteristics of modern critique of the economy or modern critique of economic thought as well. The mixing-up of all these things may generate confusion and ambivalence, but it is precisely this otherwise usual mixture of aspects that I want to address in this paper. The notion of "naturalism" is also very general here: I employ it mainly in reference to the intellectual style of modern scientific thought and to the idea of natural laws, although I consider also, more prosaically, situations in which some economic things may be referred to as being natural.

What I call "breaching thought experiments” constitute here a tentative intellectual game rather than a serious research methodology. These experiments resemble, in some way, the breaching experiments developed in the tradition of ethnomethodology. ${ }^{2}$ For the purpose of this article, breaching experiments can be defined as a series of annoying questions or situations that aim at bothering a normal course of action in order to reveal what normality is made of, or at least to point to some features of interest. The idea here is to test the behavior of economic reason in some odd situations. These experiments are also thought experiments in the sense that they do not correspond to actual, empirically monitored events. But they are not fully imaginary, however, because they are based on experience gathered in real conversations with economists or with scholars that criticize economics, in real observations of such conversations, in real exposure to economic scholarly publications and in real selfexercising of economic reasoning and of economic critique. The reader is kindly asked to add her own considerations to mine, as both a potential experimenter and a potential experimental subject. But, before pursuing with the experiments, I shall provide an introductory comment with more details about the performativity of economics and about naturalistic style in economic reasoning.

\section{Performativity and naturalism}

Scholarly speaking, and although the notion of performativity is connected to a wide variety of academic concerns and intellectual traditions, the precise topic of the performativity of economics is often defined as an emerging research program resulting from the penetration of

\footnotetext{
${ }^{2}$ Harold Garfinkel, Studies in Ethnomethodology (Englewood Cliffs, NJ: Prentice-Hall, 1967).
} 
science and technology studies into economic sociology. ${ }^{3}$ The extent to which the natural sciences do shape the world they scrutinize has been explored at length in science and technology studies. ${ }^{4}$ This works for the social sciences too, and it is probably Michel Callon’s proposal that best characterizes the move towards economics: studying the ways in which the sciences of the economy do shape their objects would be the first move towards a renewal of the sociological understanding of how markets themselves are constructed. ${ }^{5}$

Empirical work such as the one undertaken by Donald MacKenzie on the role of financial theory in the construction of contemporary financial markets puts forward the extent to which a sound sociological analysis of economic things needs including economics and its effects among its objects of inquiry. ${ }^{6}$ As more and more markets appear nowadays as made out of market sciences (economics at large, including finance, marketing, accounting and other market-enabling disciplines), this empirical stake cannot but make sense. But Michel Callon's formulation of this research direction points out some rather radical theoretical implications that challenge — to some extent and in clear resonance with actor-network theory — the usual tenets of economic sociology. ${ }^{7}$

\footnotetext{
${ }^{3}$ See, for instance, Marion Fourcade, “Theories of Markets and Theories of Society,” American Behavioral Scientist 50 (2007): 1015-34.

${ }^{4}$ See, for instance, Ian Hacking, Representing and Intervening: Introductory Topics in the Philosophy of Natural Science (Cambridge: Cambridge University Press, 1983); Bruno Latour, Science in Action: How to Follow Scientists and Engineers through Society (Cambridge, MA: Harvard University Press, 1987); Andrew Pickering, The Mangle of Practice: Time, Agency and Science (Chicago, IL: University of Chicago Press, 1995); Peter Galison, Image and Logic: A Material Culture of Microphysics (Chicago, IL: University of Chicago Press, 1997). For a cogent overview, see Casper Bruun Jensen, “A Nonhumanist Disposition: On Performativity, Practical Ontology, and Intervention,” Configurations 12 (2004), 229-61.

${ }^{5}$ Michel Callon, “Introduction: The Embeddedness of Economic Markets in Economics,” in The Laws of the Markets, ed. Michel Callon (Oxford: Blackwell, 1998), 1-57.

${ }^{6}$ Donald MacKenzie, An Engine, not a Camera: How Financial Models Shape Markets (Cambridge, MA: The MIT Press); MacKenzie, “Is Economics Performative? Option Theory and the Construction of Derivative Markets,” in MacKenzie et al., Do Economists Make Markets?, 54-86.

${ }^{7}$ Michel Callon, “What Does it Mean to Say that Economics is Performative?,” in MacKenzie et al., Do Economists Make Markets?, 311-357. Actor-network theory, a scholarly viewpoint of which Michel Callon is an active proponent, originated as both a materialist approach to the study of science and technology and a pragmatist critique of regular sociological explanatory categories. See Bruno Latour, Reassembling the Social: An Introduction to Actor-Network-Theory (Oxford: Oxford University Press, 2005).
} 
Although it is more than reasonable to acknowledge the fact that economists, with their tools and theories, sometimes intervene in the construction of markets, to consider that usual economic things such as “economic preferences”, "marginal utility”, “transaction costs”, “equilibrium prices”, “rational expectations”, “aggregate demand”, “credit risk” or "return on capital" are not naturally-occurring things but rather artificial things which are always the outcome of an intense work of constitution - a work that includes the sciences of the economy among its key ingredients — is probably a more disturbing idea, an idea whose disturbance is best summarized by the provocative adage that can be extracted from Michel Callon's proposal: that "the economy is embedded not in society but in economics." ${ }^{8}$ Further disturbance is added to this by the fact that the problem of truth and falsehood, a problem to which sciences (economic or otherwise) are usually expected to be exposed to, is neatly disregarded, within this viewpoint, in favor of the problem of success and failure. This challenges indeed the efficacy of a purely epistemological critique of economics: the truth or falsehood of economics depends now on its capacity to construct worlds in which its claims can hold together, not on any natural adequacy of these claims to their external objects. ${ }^{9}$ Performativity would thus hamper not only science but also, more fatally, the rational critique of science - and these annoyances echo, of course, the objections to constructivism that have often animated science and technology studies in the case of the natural sciences. ${ }^{10}$ The idea of the performativity of economics has been indeed critiqued in these or similar terms, sometimes with an explicit reference to its connections to actor-network theory. ${ }^{11}$ In substance, this idea, it is said, would remove the strength of an epistemological critique of

\footnotetext{
${ }^{8}$ Callon, “Introduction”, in The Laws of the Markets, quote from page 30.

${ }^{9}$ Francesco Guala’s phrasing conveys this idea well: “Economic rationality is not like Newton’s laws, which are supposed to be at work everywhere in the universe. It is a fragile property that must be carefully preserved by creating a hospitable environment.” Francesco Guala, "How to Do Things with Experimental Economics,” in MacKenzie et al., Do Economists Make Markets?, 128-62, quote from page 147.

${ }^{10}$ Michel Callon, “Whose Imposture? Physicists at War with the Third Person,” Social Studies of Science 29 (1999): 261-86.

${ }^{11}$ Daniel Miller, “Turning Callon the Right Way Up,” Economy and Society 31 (2002): 218-33; Ben Fine, “Callonistics: A Disentanglement,” Economy and Society 32 (2003), 47-84; 2003; Philip Mirowski and Edward Nik-Khah, "Markets Made Flesh: Performativity, and a Problem in Science Studies, Augmented with Consideration of the FCC Auctions,” in MacKenzie et al., Do Economists Make Markets?, 190-224. Of course, I condense here critiques in a way that deprives them from their original scholarly contextualization. The purpose is not to discuss them but to use them as stylized vehicles for a wider reflection on naturalism as a problematic feature of modern economic reason.
} 
economics (i.e. a critique signaling a lack of truth in scientific statements), and also possibly of a sociological critique (i.e. a critique signaling social, explanatory forces more fundamental and effective than the work of economics).

The cultures of scientific thinking and scientific practice, the attachment to ideals of natural inquiry and intellectual critique in modern thought, and the connections of all this to the development of the modern world itself are at the center of a number of contributions to the history of science and to the anthropology of scientific activities. Modern reason has thus been scrutinized in more than one way and put to the test of various forms of historical and anthropological contextualization. As it is aptly put in the promotional jacket of a recently published book, “objectivity has a history, and it is full of surprises.”" 12 One particularly ambitious anthropological venture in this line is the inclusion of modern scientific thought into the structural classification of the different modes of identification of beings undertaken by Philippe Descola. ${ }^{13}$ Descola classifies, in a structural fashion, the several ways in which human beings might consider their interiority, and this interiority's relations to external beings, especially to beings other than other human beings. Naturalism is, according to this classification, a structure of intellection characterized by a univocal and exterior nature. Within a naturalistic mode of intellection, there might be several interiorities, preferably human (i.e. human subjects), but all beings (including human beings but not only) share a similar physicality. The modern scientist can thus talk about multiculturalism (several cultures, several ways of thinking and of seeing things, several ways of experiencing human interiority), but never about "multinaturalism” (since there is only one nature). But human beings have lived and still can live without partaking of this form of thought. In animism, another section of Descola's classification, all beings (and not exclusively human ones) are similar in the sense that they all share similar interiorities. But they are different in the sense that they have different physicalities. From an animist perspective (for instance in Amazonian thought), everything has a soul, everything is a person. Trees have a soul, animals have a soul, and rivers have a soul. And all souls are similar in kind. But everything might not share the

\footnotetext{
${ }^{12}$ Lorraine Daston and Peter Galison, ed., Objectivity (New York, NY: Zone Books, 2007).

${ }^{13}$ Philippe Descola, Par-delà nature et culture (Paris: Gallimard, 2005). See also Descola, In the Society of Nature: A Native Ecology in Amazonia (Cambridge: Cambridge University Press, 1996).
} 
same nature. A soul may have different bodies that live in different natures. ${ }^{14}$ In animism, there is certainty about the universality of spirit, but there is uncertainty about the universality of body and matter. ${ }^{15}$

One important hypothesis defended by scholars interested in the particular style of Western modern reason is that the latter is plainly naturalistic. Human beings are strictly distinguished from other beings. They distinguish themselves because they have one kind of interiority that we call subjectivity and which might be idiosyncratic. But they all share among them and with other beings a similar physicality, in the sense that they share the same laws of nature. Bodies are bodies here and elsewhere. Molecules are molecules here and elsewhere. Radiation is radiation here and elsewhere. The self-evident outcome of that state of mind is modern scientific inquiry. Galileo's motto is crucial in this characterization of naturalism: the book of nature might not be easy to read, but there is surely only one and it is written in mathematical language, i.e. a language prone to scientific reading. Authors such as Bruno Latour, however, have opposed meticulously this version of what modern thought is and of how it operates. ${ }^{16}$ For Latour, naturalism corresponds to the picture modern science keenly provides of itself, but is at odds with what modern science really does. According to Latour, the archetypical modern thinker speaks with a forked tongue, praising naturalism, pretending to be a naturalistic-minded inquirer, but in practice not stopping from producing hybrids, from entangling human beings and other beings and from provoking nature rather than unveiling it. Such duplicitous manners constitute probably the main outcome of the symmetric anthropology of modern reason undertaken by Bruno Latour.

\footnotetext{
${ }^{14}$ Eduardo Viveiros de Castro uses the notion of "multinaturalism” to characterize this feature of Amazonian thought: Eduardo Viveiros de Castro, “Cosmological Deixis and Amerindian Perspectivism,” Journal of the Royal Anthropological Institute 4 (1998): 469-88; Viveiros de Castro, "Exchanging Perspectives: The Transformation of Objects into Subjects in Amerindian Ontologies,” Common Knowledge 10 (2004): $463-84$. See also Bruno Latour, Politics of Nature: How to Bring the Sciences into Democracy (Cambridge, MA: Harvard University Press, 2004).

15 The structural classification proposed by Philippe Descola adds to naturalism and animism two other forms of intellection, which are totemism and analogism. In naturalism, the universality of physicality is linked to the contingency of interiorities. In animism, the generalization of interiority is a counterpoint to the differentiation of physicalities. Totemism is characterized by a moral and material continuity of physicality and interiority. Analogism is the realm of multiple differences at both levels, and of multiple networks of correspondence that make the world readable as an ongoing chain of relations.

${ }^{16}$ Bruno Latour, We Have Never Been Modern (Cambridge, MA: Harvard University Press, 1993).
} 
Is naturalism a fundamental characteristic of economic thought? Or is economics an instance of the modern forked tongue? My purpose in this paper is not (and could not be) to try to settle this issue. It is, at best, to provide some elements that could help considering the case of economic reason with a few observations on the "naturalistic style" often displayed in economics or about economics. The claim on the performativity of economics can intervene in this inquiry as an assertion that breaches the naturalistic style of economic thought, but also as a test of the forked tongue hypothesis. In what follows, I propose a series of situations (which I have referred to as "breaching thought experiments”) that allow characterizing several aspects of this question.

\section{Experiment 1: name both science and object}

It is easy to recognize in economics a sort of a naturalistic style, which is of course acknowledged to a great extent. We may all have different cultures, opinions, beliefs, but we all share the same economic laws. Money is money here and elsewhere. Budgetary constraints are budgetary constraints here and elsewhere. Marginal utility is marginal utility here and elsewhere. We may have all different preferences, but we all certainly have such a thing as “economic preferences” that can be taken into account economically and aggregated together into some sort of an economic calculation. Any sort of process, regardless of its particular point and scope, as soon as it is costly (and any process may be costly) is economic in nature and thus prone to economic analysis. Economic characteristics do characterize individuals, but also groups, families, countries, firms, and also natural resources, ecosystems, animals or, why not, cells, neurons and computer programs. This seems naturalistic indeed: a reason that goes through all and unifies all, an economic nature that is transversal to all bodies and to all souls. Is economic reason the paramount naturalistic reason?

Let me point to a most curious index of naturalization that characterizes economic reason, an index that is actually more visible in French that in English. Although in the English vocabulary a difference is often drawn between economics (the science) and the economy (the thing), in French the same word may be used to refer to both: économie. L'économie is "the economy", but also "economics" in the sense of the academic discipline. The later can also be referred to as sciences économiques, but économie corresponds to a 
fairly widespread use, especially among professionals of the discipline. Note the oddity: for the study of société (society), you have sociologie (sociology); for coeur (the heart) you have cardiologie (cardiology); for minerais (minerals) you have minéralogie (mineralogy); but for the study of économie, you have économie. ${ }^{17}$ A science that calls itself just like its object: this may look like an extreme symptom of naturalism, or maybe rather like a brilliant coup of naturalization.

Of course, such anecdotal comments should not stand in place of references to a long and fruitful tradition in the history of ideas that explores the naturalistic style in economic reason. This tradition has studied at length the construction of the categories of modern economics, starting with the notion of economic individual, the notion of self-interest, the notion of utility, and so forth, including also the study of how mathematics and formalistic languages in general have allowed economics to emancipate, as a science, from moral philosophy. ${ }^{18}$ But it is nonetheless interesting to stop at issues such as the ordinary naming of economics. Is economics the knowledge or the object of knowledge? In French, this question (our first "breaching thought experiment”) is in effect slightly annoying, and revealing. And perhaps in English too, especially in American English, a language in which a political speech on "economics" can indeed meant to be on the current state of affairs in the national economy or, conversely, praise for the importance of "the economy" can indeed signify a call for more attention to scientific economic thinking. ${ }^{19}$

\footnotetext{
${ }^{17}$ In a staged version, this first "breaching thought experiment” could consist in playing, in the conversation, with what would have been a logical guess for the name of the science: "Vous voulez dire économicologie" ("You mean economicology”). This instance of a "breaching thought experiment" is based on a real conversation with a British academic on how to translate slightly ambiguous expressions like "économie des conventions" or "économie alternative”, for which both “economics” and “economy” may make sense.

${ }^{18}$ See, for instance, Louis Dumont, Essays on Individualism: Modern Ideology in Anthropological Perspective (Chicago, IL: University of Chicago Press, 1992); Jean-Pierre Dupuy, Le sacrifice et l'envie: le libéralisme aux prises avec la justice sociale (Paris: Grasset, 1992); Bruna Ingrao and Giorgio Israel, The Invisible Hand: Economic Equilibrium in the History of Science (Cambridge, MA: The MIT Press, 1990); Pierre Demeulenaere, Homo oeconomicus: enquête sur la constitution d'un paradigme (Paris: Presses Universitaires de France, 1996).

${ }^{19}$ For an interesting reflection on the origins of the notion of "the economy", see Timothy Mitchell, "Fixing the Economy,” Cultural Studies 12 (1998): 82-101; Mitchell, Rule of Experts: Egypt, Techno-politics, Modernity (Berkeley, CA: University of California Press, 2002); Manu Goswami, Producing India: From Colonial Economy to National Space (Chicago, IL: University of Chicago Press).
} 


\section{Experiment 2: the object of economics (natural or social)}

Consider economics (the science) as a whole and ask the question of its object. More prosaically, ask to an economist: “What kind of object does your science look at?” You may then introduce some annoying element and refine the question as follows: "But do you study objects which are natural or which are social?” Insist: “Is your science a social science or a natural science?”

Well, of course, we may easily say that economics study the economy, and that the economy is a human invention, so the science that studies it is therefore a human or social science. However, the experiment is far from providing such a straightforward conclusion. When you tell an economist that her science should naturally side with the humanities or the social sciences, an expression of discomfort or of slight doubt may arise, especially among economists from a highly quantitative or mathematical tradition. Such kind of expression of doubt or discomfort may arise spontaneously, in multidisciplinary gatherings in which, say, economists and sociologists negotiate a common institutional tag. It is usual, for instance, to use labels such as “economic and social sciences” ("sciences économiques et sociales” in French) in order to refer to scholarly institutional arrangements (academic departmental sections or research councils, for instance) that are to encompass both economics and other sciences such as sociology, anthropology or political sciences. But does this mean economics and the rest of the social sciences? Or does this rather mean economics and other sciences which are different because they are social? There is, indeed, a doubt. ${ }^{20}$ Some economists would spontaneously praise for the difference, others would find that odd, others may say: "Well, yes, economics is a social science too indeed, but it is a different sort of social science because it is a hard science."

There are myriad possible answers to that question. But many may carry some hesitation. Nuances, in any case, need to be put forward in order to make sense of a difference that does not seem to be quite comfortably acceptable. What is this hesitation about? Not

\footnotetext{
${ }^{20}$ This second instance of a "breaching thought experiment" is based on one actual discussion at the seminar of an interdisciplinary academic society which includes economists, sociologists, anthropologists and political scientists as members and which hosts a monthly "social studies of finance” research seminar in Paris.
} 
exactly, I believe, about the object of economics as such. The object of economics is probably quite clear for economists as well as for other scholars: it is the economy, it is economic processes. The hesitation comes when economics is asked to stick to one of two boxes: nature or culture, social or natural. Because economic things, even if they are things of culture (human things), are also perfectly natural in the sense that the laws they may follow are like the laws of nature - and explicitly not like those other laws we primarily refer to as politically instituted conventions.

This imaginary test is meant to produce exaggeration and, of course, does not make justice to the variety of approaches (including heterodox ones) that there exists in economics, or to the fact that some specialties in sociology, political sciences or psychology may share similar features too. But it is now accepted that the hardcore of economics (i.e. its mainstream or more legitimized components) has been fighting to side with the hardest sciences, such as physics. ${ }^{21}$ And the entanglements of economics with the hard sciences are not only a matter of shared use of scientific tropes. Training in physics or mathematics as become a usual feature (if not a requisite) of the curricula that lead to a brilliant career in the trading rooms of international investment banks. Would quantitative finance side with the social sciences or with the natural sciences? How would it behave in our first "breaching thought experiment"? Will it actually try to go beyond this divide, just as the "cyborg sciences" try to do? And what about other avant-garde forms of economics such as computational economics? Economics gives itself, as an object of inquiry, something that is visibly human. But economics prefers to describe itself as a natural science or rather as a "general” science, with a transversal object called "economy", and object beyond nature and culture, just as pioneering cybernetics got itself a similarly transversal object called "information.",22

\footnotetext{
${ }^{21}$ Philip Mirowski, More Heat than Light: Economics as Social Physics, Physics as Nature’s Economics (Cambridge: Cambridge University Press, 1989).

${ }^{22}$ Philip Mirowski, Machine Dreams: Economics Becomes a Cyborg Science (Cambridge, Cambridge University Press, 2002).
} 


\section{Experiment 3: money in a constructivist situation}

Let us explore further these strange features of the style of economic reason. The economy is probably one site in which the expression "social construction of" is less meaningful. To say that the economy is socially constructed may be as pointless as saying that society is socially constructed: of course it is. Economic institutions are artificial by definition. Money is a cultural artifact, and so are the market, the factory and the firm. Economy is done, made up, not given in nature. Even economists from the hardest laissez-faire traditions can agree on this. But, by a strange loop of reason, economic categories suddenly appear as more natural than natural. Economic laws are not laws in the primary sense of the word, which means political rules instituted by human beings, but laws in the sense of the laws of nature, which are universal and independent from any political endeavor. This loop, this drift of economic reason, does not only happen among economists. Of course, they are the first to benefit from this effect of naturalization or of exteriority. But this loop is shared by everybody, in a certain sense, and shared specifically by critiques of economics.

The setting of our third "breaching thought experiment" is a constructivist situation: a scholarly conference in which radically constructivist or relativist perspectives are used in order to address objects which are usually considered as natural realities, such as physical space or time. This could be, for instance, a conference on science and technology studies. ${ }^{23}$ In this setting, it is possible to attend lectures or presentations in which categories as hard as time and space (i.e. primary qualities, in the philosophical sense) are said to actually look universal only because of an intense work that accomplishes them as universal. ${ }^{24}$ But, some attendees would convincingly explain, since this work is partial and contingent, this leads indeed to a multiplicity of forms of organizing spacing and timing, best referred to as verbs. ${ }^{25}$ Imagine a moment in which, against this constructivist background (which is not quite naturalistic indeed), the issue of money is raised. Prefer a situation in which money (or capital or markets) is critically presented as some universal machinery that creates abstraction and

\footnotetext{
${ }^{23}$ This instance of a "breaching thought experiment" is inspired by observations at one panel discussion at the annual meeting of the Society for Social Studies of Science in 2004.

${ }^{24}$ A particularly helpful introduction to the analysis of the role of metrology in the construction of universality is Joseph O'Connell, “Metrology: The Creation of Universality by the Circulation of Particulars," Social Studies of Science 23 (1993): 129-73.

${ }^{25}$ Geoff Jones, Christine McLean and Paolo Quattrone, “Spacing and Timing,” Organization 11 (2004): 723-41.
} 
renders all things and beings commensurable and alienable, and which therefore informs, or constructs, particularly globalized and uniformed forms of timing and spacing. The breach is introduced by a redirection of constructivism to money, perhaps with a naïve remark such as: "But I thought money was the thing that was socially constructed.”

When economic things (money, capital, markets) appear as explanatory factors in radically constructivists accounts of supposedly natural things (space, time), one could expect an equitable use of constructivism. Actually, one could have thought of money as an easier target to relativism than time or space. There might exist several spaces and several times, but there surely exist several monies, several types of markets and several accounting methods. ${ }^{26}$ And still, economic categories can intervene in a constructivist appraisal of the natural world in a much unconstructed fashion: as universal realities that provide a univocal explanation of global unity. The continuity of time and space might be an illusion. But capital is the ultimate primary quality. The outcome of this somehow likely "breaching thought experiment" is the relative resistance to constructivism of economic reasoning, the tendency of economics to side with explanatory variables instead of with constructed ones or, better, to stand as a fixed point around which turns the rest of the world.

\section{Experiment 4: the question of fiction and reality}

Ask an economist: “Are your models fictitious or real?” This is a test on the ambivalence of economics toward its object. Economics has often been accused of dealing with fictional objects. $^{27}$ This is particularly the case for economic theory in the neoclassical tradition and for

\footnotetext{
${ }^{26}$ See, for instance, Nigel Dodd, The Sociology of Money: Economics, Reason and Contemporary Society (Cambridge: Polity Press, 1994); Viviana A. Zelizer, The Social Meaning of Money: Pin Money, Paychecks, Poor Relief, and Other Currencies (Princeton, NJ: Princeton University Press, 1997); Anthony G. Hopwood and Peter Miller, ed., Accounting as Social and Institutional Practice (Cambridge: Cambridge University Press, 1994); Michael Power, ed., Accounting and Science: Natural Inquiry and Commercial Reason (Cambridge: Cambridge University Press, 1996).

${ }^{27}$ On the scholastic fallacies of economics, see for instance Pierre Bourdieu, "Le champ économique,” Actes de la Recherche en Sciences Sociales 119 (1997): 48-66; Bourdieu, The Social Structures of the Economy (Cambridge: Polity Press, 2005). On the problems of critiquing the unrealism of assumptions in economics, see
} 
purely model-based economic science. Microeconomic models or game-theoretical models deal with market configurations that are unreal in the sense that they are composed of minimalist actors who exchange minimalist goods with minimalist money in a minimalist setting, and that attain situations of equilibrium or disequilibrium that we can legitimately call, also, minimalist.

What do economists say to that? Many may complain against this critique and claim realism instead (realism of assumptions, realism of data fed into the models). But some (good ones) may also acknowledge the fictional status of economic models, and even add that fiction is not an unintended flaw of their science but a purposeful rational device. ${ }^{28}$ The ambition of economic theory, will they answer, is not to describe what happens in the real world but to isolate and comprehend a mechanism that is precisely almost impossible to isolate "in vivo": hence the need to abstract it, e.g. to simulate or to model it. ${ }^{29}$ This answer, sophisticated but probable among economists with sufficient epistemological curiosity, seems quite reasonable. But it comes with a strange supplement. The economist produces a theoretical fiction, develops a model or an experimental setting that describes the functioning of that fiction, deploys a number of implications and consequences of this functioning and, little by little, this deployment starts to navigate into the world "out there”, to circulate within regulatory bodies, consultancy firms, banks, government departments, and to flow in what we curiously call the "real economy", as opposed to the presumably "unreal economy" of economics. ${ }^{30}$ Of the many examples of this sort of movement from abstracted theorizing to economic implementation, perhaps the neoclassical theory from the Chicago School and the reconfiguration of the Chilean economy by the "Chicago Boys" under Augusto Pinochet is a

Nancy Cartwright, The Dappled World: A Study of the Boundaries of Science (Cambridge, Cambridge University Press, 1999).

${ }^{28}$ This fourth "breaching thought experiment" is based on memories from undergraduate courses in macroeconomics and discussions with fellow students on the realism of economics at the Universidad Autónoma de Madrid.

${ }^{29}$ The question of abstraction constitutes a difficult topic for the critique of economics, in the sense that "abstract" is often implicitly taken as a synonym of "not real" — at the risk, consequently, of making it not worthy of critique (on the ground that it is better to spend time criticizing things that do exist rather than things that do not exist).

${ }^{30}$ I am unaware of any study on the origins of the expression "real economy,” but I conjecture that it was probably invented in relation to economics to denote what this science is not about. 
particularly salient one. ${ }^{31}$ If addressed at these economists and their teachers, our "breaching thought experiment” might have triggered an interesting set of well-structured but at some point slightly paradoxical reactions, wavering between a lesson on the distinction between normative and positive economics and a comment on the political usefulness of being scientifically right.

Is this another example of modernistic forked tongue? Do economists tell they unveil economic laws but then actually institute them? Even in the hardest laissez-faire traditions of contemporary neoliberal economics, there is a realist sense of the fact that markets are constructed and that economists may need to work as constructors if they want to achieve their policy project, as pointed out by Michel Foucault in the case of neoliberal economics. ${ }^{32}$ Perhaps the key to this experiment does not lie in the choice between reality and fiction (several compromises are possible in this respect) but in the position of the narrator as an author - of fictions or of realities. The economist can claim authorship of her axiomatic models without much trouble. But she would probably prefer to fade out in favor of markets themselves as authors of economic realities. This ellipsis is particularly important to neoliberal approaches, since, according to these, markets are supposed to be more intelligent than economists.

\section{Experiment 5: economics is performative}

Let us now turn to a "natural-occurring experiment”: Michel Callon’s programmatic call and some subsequent critical reactions. ${ }^{33}$ I use some of the critics here, with all respect due, as the victims of one imaginary "breaching thought experiment" on the polemical behavior of

\footnotetext{
${ }^{31}$ Juan Gabriel Valdés, Pinochet's Economists: The Chicago School in Chile (Cambridge: Cambridge University Press, 1995).

${ }^{32}$ Michel Foucault, The Birth of Biopolitics: Lectures at the College de France, 1978-1979 (New York, NY: Palgrave Macmillan, 2008).

${ }^{33}$ Callon, "Introduction", in The Laws of the Markets. This last instance of a "breaching thought experiment" is inspired by the discussions that took place during a workshop on the "performativities of economics" held in Paris in August 2004. A number of papers presented at the workshop evolved into contributions to MacKenzie et al., Do Economists Make Markets?, others were part of Michel Callon, Yuval Millo and Fabian Muniesa, ed., Market Devices (Oxford: Blackwell, 2007).
} 
economic reason. In particular, I use the critique put forward by Daniel Miller and by Philip Mirowski, two scholars from different academic domains (the first is an anthropologist of markets and the second is an heterodox economist and historian of science) but that do have in common an explicit critique of mainstream economic science. ${ }^{34}$

In his critique of Callon as well as in earlier work, Daniel Miller proposes a theoretical framework to tackle the impact that economists, their theories and their models might have in real economies. ${ }^{35}$ Although this might seem comparable to Michel Callon’s proposal, Miller sees in Callon's viewpoint a threat: the research direction defended by Callon may hamper the sociological critique of economics and turn into a defense of the power of economics instead. For Miller, if the market that is envisioned by economists can have a real impact in economic reality, it is more as an ideological model than as an empirically operational tool. Economists produce views, models and doctrines which remain essentially abstract. These may hold as viewpoints in order to justify action. But they cannot form a durable world. The reason why is that economic reality is not like economists posit it, but is constituted instead by social bonds and power relations, i.e. it is socially constituted. These are phenomena that only a proper economic sociology can analyze. But sociology then needs to emancipate from the illusion of economics: the illusion of the existence of detached rational agents in a world of calculation. Talking about the performative efficacy of economics in constructing such world of calculation would be a way of taking stock in this illusion. ${ }^{36}$

\footnotetext{
${ }^{34}$ My opinion is that the most relevant ingredient of the critique of the thesis of the performativity of economics (far more than definitional subtleties or empirical evidence and counterevidence) is infuriation, which is why I think this critique is prone to the treatment I offer here.

${ }^{35}$ Miller, “Turning Callon the Right Way Up.” See also James G. Carrier and Daniel Miller, ed., Virtualism: A New Political Economy (Oxford: Berg, 1998).

${ }^{36}$ A follow up of this discussion can be read in a series of reactions and of further clarifications: Michel Callon, "Why Virtualism Paves the Way to Political Impotence: A Reply to Daniel Miller's Critique of The Laws of the Markets”, Economic Sociology European Electronic Newsletter 6(2) (2005): 3-20; Daniel Miller, "Reply to Michel Callon”, Economic Sociology European Electronic Newsletter 6(3) (2005): 3-13. See also Andrew Barry and Don Slater, ed., The Technological Economy (London: Routledge, 2005) and Petter Holm, "Which way is up on Callon?,” in MacKenzie et al., Do Economists Make Markets?, 225-43.
} 
The arguments of Philip Mirowski and his co-author Edward Nik-Khah are comparable to Miller's, although not exactly equivalent. ${ }^{37}$ Science studies come here at the forefront, but rather as a tool to examine the ideas and epistemic constraints that govern the intellectual ventures and professional biographies of economists. One major contribution of Mirowski's history of economics is to show that economics (especially within neoclassical or associated paradigms) is essentially defective. ${ }^{38}$ For Mirowski, Callon's notion of performativity suggests that, even being false, an economic theory may pretend to veracity just because of its pragmatic success. Again, this is the same as siding with the economists. Because economists can impose their economic machines they can also aim, with the help of Michel Callon, at being scientifically right: this is probably what most infuriates Mirowski. If, by any chance, some economists or some devices coming out from their science get involved in some social engineering, such as the construction of a market, this is not at all due to any performative aspect of their science. It is, above all, a matter of power and economic interests. It is not economists who perform, it is the powerful. Callon, according to Mirowski, takes our critical eye away from this fact, away from the explanatory power of social forces - or economic forces, which seems to be the same anyway, since we deal here with capitalism. ${ }^{39}$

These scholars, convinced of the interest of combining an examination of economics and a sociological critique of effective economic practices, are alarmed by an hypothesis that seems empirically reasonable but that can become an unsupportable threat to the critique of

\footnotetext{
${ }^{37}$ Mirowski and Nik-Khah, “Markets Made Flesh,” in MacKenzie et al., Do Economists Make Markets?. An almost identical version of the argument is published as Philip Mirowski and Edward Nik-Khah, “Command Performance: Exploring What STS Thinks It Takes to Build a Market,” in Trevor Pinch and Richard Swedberg, ed., Living in a Material World: Economic Sociology Meets Science and Technology Studies (Camdridge, MA: The MIT Press, 2008), 89-128.

${ }^{38}$ Philip Mirowski, The Effortless Economy of Science? (Durham, NC: Duke University Press, 2004).

${ }^{39}$ The empirical parts of the critique by Mirowski and Nik-Khah focus on an article by Francesco Guala on the role played by economics (game theory and experimental economics) in the construction of spectrum auctions: Francesco Guala, “Building Economic Machines: the FCC Auctions”, Studies in History and Philosophy of Science 32 (2001): 453-477. A further exchange is available in Edward Nik-Khah, "What the FCC Auctions Can Tell Us About the Performativity Thesis”, Economic Sociology European Electronic Newsletter 7(2) (2006): 1521; Francesco Guala, “Getting the FCC Auctions Straight: A Reply to Nik-Khah”, Economic Sociology European Electronic Newsletter 7(3) (2006): 23-28; Callon, "What Does it Mean to Say that Economics is Performative?,” in MacKenzie et al., Do Economists Make Markets?; Edward Nik-Khah, “A Tale of Two Auctions”, Journal of Institutional Economics 4(1) (2008): 73-97.
} 
economics. My suggestion is that the alarm triggered by this test reveals some difficulties of the naturalistic style of economic reason. At the core of this dispute lies the crucial question of the truth of economic reasoning, a question that, as any other question about truth, may be indeed disturbed by any pragmatist idea (in the philosophical sense), as the idea of performativity is. The problem is that this critical resistance ends up enforcing a strange alliance between economic science and economic critique. These critics need to face a difficult paradox. The principal claim is that it is necessary to criticize economics: Callon should criticize economics and the reason why is that economics is false, in the sense that it does not account for reality. And then follows that economics cannot be performative: as science, it fails from having any effect on reality, it literally does not matter. But then a crucial question needs to be asked: why should we waste time criticizing something that does not matter?

The answer, I believe, has to do with something (a style of thought) that these exemplary critical voices might share with their critiqued economists. ${ }^{40}$ There is agreement on the fact that the aim of economic science should be to describe and comprehend the world (critically or not), but not to provoke it. The debate is on the kind of economic science that can do that rightly or wrongly. But, although there is disagreement on how to be positive about the stuff the economy is made off, there is conformity on the fact that the economy is out there, as an operating variable that needs to be captured. What Callon says — namely that there is no economic anything without a process of economization - cannot be easily admitted, perhaps because what is out there (let us call it nature) is ultimately thought to be already written in economic language. ${ }^{41}$

\footnotetext{
${ }^{40}$ I put here the topic of academic socialization and scholarly habits aside.

${ }^{41}$ If we play with Descola's structural categories, we could think of the role of Callon in this "breaching thought experiment” as impersonating the menace of analogism over naturalism, i.e. the menace of a style of intellection that would be attentive to varied correspondences between economists and economies, both imitating each other, engendering each other.
} 


\section{By way of conclusion}

I believe that some naturalistic style intervenes at the surface of economics, but that the hypothesis of the modern forked tongue (claiming naturalism while blatantly performing) applies also quite well to the case of economic reason. Maybe our five "breaching thought experiments" (a method of inquiry that I think is worthwhile considering effective to a certain extent) serve the clarification of this point well. The first experiment (on the naming of economic science) brought evidence of a naturalizing subconscious in economic academic parlance. The second experiment (on economics as social or natural science) revealed a highly unchallenged universalism, with an object that is highly general and undetermined. The third experiment (on economics in constructivist situations) demonstrated a high degree of resistance of economics to any kind of relativism or constructivism. The fourth experiment (on the fictitious character of economic theory) made explicit some ambivalence on the reality of the object of economics. The fifth experiment (on the performativity of economics) pointed to some traumatic features of the modern critical position when it comes down to economics.

Perhaps our fifth experiment focused too much on the potential behavior of the critique of economics and failed to address the behavior of economics itself. How would the paramount modern economist react to the idea, preferably formulated in a bold manner, that her science provokes the world it studies? Will she be shocked? Or would she rather remain indifferent? ${ }^{42}$ She might just say something along the line of: "Yeah, thanks, we knew already.” Adding perhaps: "But if we do that it’s because we’re right.” Performative pride, wrapped up into a naturalistic epistemological layer? That is only a hypothesis, but a plausible and interesting one. When you say that the book of nature is written in economic language but then you get caught in the act with that book in one hand and a pen in the other, well, the wisest thing to do is probably to smile at the camera and say that, ok, you were writing it but you were writing it nicely. On the overall, it is interesting to note that the performativity

\footnotetext{
${ }^{42}$ In recent critical comments on the topic of the performativity of economics, David Colander (a reputable economist) says among other things that he does not understand the notion of performativity very well, that he dislikes it and finds it irritating, that proponents in that field think this topic is new but in reality it is not, that the point is about signaling a contradiction in economics but that there is no such contradiction, that most economists are indifferent to science studies and would not care about this discussion, and, finally, that economics should perform more and better: David Colander, “Review of Do Economists Make Markets?”, Journal of Economic Literature 46(3) (2008): 720-724.
} 
breaching experiment seems to be perceived as a shock more by critics of economics that by economists themselves. If we consider this test as a test that excites naturalistic style, this would mean that naturalism affect economic reason the better when this reason is critical. This is serious, because it would mean that the critique of economic reason would be indeed more tied to the naturalization of economic categories than economics is. If true, this would be a bit sad — although hopefully not definitive. 